\title{
REE in waters and bottom sediments of salt lakes of Southeastern Transbaikalia, Russia
}

\author{
Svetlana V. Borzenko ${ }^{1, *}$, and Leonid V. Zamana ${ }^{1}$ \\ ${ }^{1}$ Institute of Natural Resources, Ecology and Cryology SB RAS, 672014 Chita, Russia
}

\begin{abstract}
This paper presents our analysis of the distribution of REE in mineral chloride and soda lakes of Southeastern Transbaikalia. With increasing water salinity, it was determined that concentrations of dissolved HREE increased. The prevalence in absolute concentrations of MREE and HREE was observed in lakes with the development of bacterial processes (sulfate-reduction). A geochemical barrier for accumulating the LREE in the waters can be fluoro-carbonates. The saturation degree of fluorcarbonates in soda lakes can be several orders higher than in chloride lakes. Under oxidizing conditions $\mathrm{Ce}(\mathrm{OH})_{4}$ can be formed and, in a reducing environment $-\mathrm{Ce}(\mathrm{OH})_{3}$.
\end{abstract}

\section{Introduction}

The distribution of rare earth elements (REE) in different types of natural waters is described in many publications and continues to be widely studied. Mineral lakes due to the diversity of their composition and salinity, and in such systems sedimentation provides great opportunities for research on hydrogeochemistry of rare earth elements and their participation in the modern sedimentation. The sorption of lanthanides by hydroxides of polyvalent metals (iron, manganese, cobalt), phosphorus compounds and others is typically considered as one of the processes, which limit accumulation of lanthanides in waters [1]. At the same time, the presence of authigenic REE minerals in the form of phosphate compounds, in particular, monazite, and fluorcarbonates of parisite and bastnäsite can be observed in sediment.

We studied REE in waters and bottom sediments of the salt lakes of Southeastern Transbaikalia to determine the dependence of the concentration on the chemical composition and salinity of the water. We also investigated the geochemical processes that limit the accumulation of REE in water, including the possibility of forming their own mineral phases as a result of their precipitation from saturated water solutions.

\section{Area of Study}

The salt lakes of southeastern Transbaikalia were tested in 2013-2016 during the driest period of the last two centuries of climatic conditions in the region, when the several hundred lakes existing in wet periods were partially filled with water [2]. The largest lake

\footnotetext{
* Corresponding author: svb 64@mail.ru
} 
in the Barun-Torey area, which has an area up to $580 \mathrm{~km}^{2}$ and a depth of $5 \mathrm{~m}$ at the maximum level, completely dried up. Most of the investigated lakes are located in the Onon-Torey plain, which was formed from Pleistocene lacustrine-alluvial sands (thickness is up to $100 \mathrm{~m}$ ); these sands are whitish due to the presence of pelitomorphic carbonates in their composition. Sandy stratum covers Mesozoic volcanic-sedimentary rocks (basalt, sandstone, siltstone) and Paleozoic metamorphic rocks (schist, metasandstone, limestone) rocks. The investigated lakes are located in the range of $600-800 \mathrm{~m}$ altitudes; they are endorheic and mostly confined to the internal drainage area within the boundaries of the Upper Amur basin. Lake salinity is determined by evaporation processes. The annual amount of precipitation within the plains is $300-400 \mathrm{~mm}$ and the evaporation from the water surface is more than $1000 \mathrm{~mm}$. The groundwaters are fresh. Intrabasin hydrobiological processes [3], especially production of organic substances and sulfatereduction [4] play an important role in the chemical composition of lake water.

The $\mathrm{pH}, \mathrm{Eh}, \mathrm{O}_{2}$, electric conductivity in water samples for the study of the chemical composition were determined at the locations. Determination of macro- and some microcomponents were performed in the Institute of Natural Resources, Ecology and Cryology, SB RAS. To define REE content we analyzed the samples, which were filtered through a filter paperwith pores of $2-3 \mu \mathrm{m}$ (total content) and a membrane filter $0.45 \mu \mathrm{m}$ (dissolved form); a suspended form was calculated by difference. Samples were acidified by ultrapure nitric acid. Tests are done by using ICP-MS method on the instrument ELEMENT 2 (Finnigan MAT) with certified multielement solutions and standards in Geochemistry Institute, SB RAS (Irkutsk). The detection limits range from 0.00001 (Tm) to 0.001 (La) $\mu \mathrm{g} / \mathrm{L}$.

The bottom sediments (silt, calcareous crust) were taken from the coastal zone of lakes where the flow of terrigenous material from the shore was virtually excluded. REE tests in the bottom sediments was carried out by using ICP-AES method on the instrument OPTIMA 2000 DV at the Geological Institute of SB RAS (Ulan-Ude). The error analysis was less than $10 \%$, the detection limit $-1.5 \times 10^{-5} \%$ with a minimum content of lanthanides in sedimentary rocks $5.0 \times 10^{-3}-2,5 \times 10^{-5} \%$ by [5].

In the analysis of REE distribution in the waters and sediments, valuesare normalized to NASC [6]. The strength of ionic solutions, activities of components, occurrence forms of chemical elements, the thermodynamic equilibrium of the lake waters with secondary minerals are calculated with the help of HG32 [7] computer program. To evaluate equilibrium we used the known solubility product (SP) of some of the mineral forms; SP for bastnäsite and parisite was calculated by us.

\section{Results and discussion}

According to basic physical and chemical indicators the studied salt lakes are divided into two geochemical types: soda ones with a predominance of the components of carbon dioxide $\left(\mathrm{HCO}_{3}{ }^{-}\right.$and $\left.\mathrm{CO}_{3}{ }^{2-}\right)$ in the anionic components and the value of $\mathrm{pH}>9.0$ and chloride ones with $\mathrm{pH}<9.0$ and the dominance of $\mathrm{Cl}^{-}$ion [8]. The main cation in the waters of both types of lakes is sodium. Salinity of soda lakes ranges from 1.17 to $58.5 \mathrm{~g} / \mathrm{L}$; salinity of chloride lakes is substantially higher - from 44.5 to $339 \mathrm{~g} / \mathrm{L}$. The average values of the physical and chemical characteristics of lakes and groundwaters are presented in Table 1. Due to bacterial sulfate-reduction, there are no sulfate lakes on the territory of Transbaikalia. More intensive sulfate-reduction processes take place in the soda lakes. The total content of reduced forms of sulfur $\left(\Sigma \mathrm{S}_{\mathrm{r}}=\mathrm{S}^{2-}+\mathrm{S}^{0}+\mathrm{S}^{4+}\right)$ is much higher than in chloride lakes (Table. 1), and $\mathrm{SO}_{4}{ }^{2-}$ content is almost 3 times less. The content of dissolved organic carbon (DOC) is 3 times higher, because its production is associated with the sulfate reduction. 
Data on the average content of REE are presented in Table 2. $\Sigma$ REE concentrations in lake waters vary over a wide range, the maximum $155.3 \mu \mathrm{g} / \mathrm{l}$ is set in the suspension of a soda lake with the highest turbidity (11500 units), contents of hydrolysate elements $\mathrm{Al}$ (17 $\mathrm{mg} / \mathrm{L}), \mathrm{Fe}(18 \mathrm{mg} / \mathrm{L}), \mathrm{Mn}(0.8 \mathrm{mg} / \mathrm{L})$ and suspended matter $(11.5 \mathrm{~g} / \mathrm{L})$. The total content of lanthanides in the dissolved form does not exceed $82.3 \mu \mathrm{g} / \mathrm{L}$. There is a linear relationship between REE and the mentioned hydrolysates (correlation coefficient $\mathrm{r}_{\mathrm{Al}}=0.93, \mathrm{r}_{\mathrm{Fe}}=0.88$, $\left.r_{M n}=0.99\right)$.

Table 1. Average values of the physical and chemical characteristics of lake and groundwaters, $\mathrm{mg} / \mathrm{L}$. Type waters: 1 - soda lakes, 2 - chloride lakes, 3 -groundwaters; $\mathrm{n}$ - number of samples.

\begin{tabular}{|l|c|c|c|c|c|c|c|c|c|c|c|c|c|c|c|c|c|}
\hline $\begin{array}{l}\text { Type } \\
\text { water }\end{array}$ & $\begin{array}{c}\mathrm{Eh}, \\
\mathrm{mV}\end{array}$ & $\mathrm{pH}$ & $\mathrm{O}_{2}$ & $\Sigma \mathrm{S}_{\mathrm{r}}$ & $\mathrm{DOC}$ & $\mathrm{CO}_{3}^{2-}$ & $\mathrm{HCO}_{3}^{-}$ & $\mathrm{SO}_{4}^{2-}$ & $\mathrm{Cl}$ & $\mathrm{F}^{-}$ & $\mathrm{Ca}^{2+}$ & $\mathrm{Mg}^{2+}$ & $\mathrm{Na}^{+}$ & $\mathrm{K}^{+}$ & $\mathrm{TDS}$ & $\mathrm{P}$ & $\mathrm{Si}$ \\
\hline $\begin{array}{l}1 \\
\mathrm{n}=78\end{array}$ & 99 & 9.58 & 8.0 & 1.3 & 188 & 1110 & 1420 & 1170 & 2910 & 14 & 11 & 59 & 3630 & 65 & 10510 & 0.8 & 2.1 \\
\hline $\begin{array}{l}2 \\
\mathrm{n}=10\end{array}$ & 30 & 8.20 & 7.1 & 0.1 & 68 & 83 & 610 & 3451 & 17780 & 7 & 100 & 3470 & 22480 & 76 & 48070 & 0.5 & 0.6 \\
\hline $\begin{array}{l}3 \\
\mathrm{n}=97\end{array}$ & 217 & 7.88 & 6.5 & - & 1 & 89 & 345 & 42 & 31 & 2 & 33 & 25 & 84 & 1 & 562 & 0.1 & 7.6 \\
\hline
\end{tabular}

Table 2. Average REE content in waters, ppb (1 - suspended, 2 - dissolved forms, GW groundwaters) and bottom sediments (3), $\mu \mathrm{g} / \mathrm{L}$.

\begin{tabular}{|c|c|c|c|c|c|c|c|c|c|c|c|c|c|c|c|}
\hline \multirow[b]{2}{*}{ Ln } & \multicolumn{3}{|c|}{ Soda lakes } & \multicolumn{3}{|c|}{ Chloride lakes } & \multirow{2}{*}{\begin{tabular}{|c|}
$\mathrm{GW}$ \\
2 \\
$\mathrm{n}=97$
\end{tabular}} & \multirow[b]{2}{*}{$\mathrm{Ln}$} & \multicolumn{3}{|c|}{ Soda lakes } & \multicolumn{3}{|c|}{ Chloride lakes } & \multirow{2}{*}{\begin{tabular}{|c|} 
GW \\
2
\end{tabular}} \\
\hline & $\begin{array}{c}1 \\
n=13\end{array}$ & $\begin{array}{c}2 \\
\mathrm{n}=78\end{array}$ & $\begin{array}{c}3 \\
n=22\end{array}$ & $\begin{array}{c}1 \\
n=4\end{array}$ & $\begin{array}{c}2 \\
n=10\end{array}$ & $\begin{array}{c}3 \\
\mathrm{n}=10 \\
\end{array}$ & & & 1 & 2 & 3 & 1 & 2 & 3 & \\
\hline $\mathrm{a}$ & 3.330 & 0.590 & 23.460 & 1.030 & 0.115 & 21.550 & 0.020 & $\mathrm{Er}$ & 0.140 & 0.092 & 1.890 & 0.100 & 0.003 & 1.750 & 0.003 \\
\hline $\mathrm{Ce}$ & 6.590 & 1.268 & 50.080 & 2.260 & 0.206 & 48.200 & 0.020 & Tm & 0.020 & 0.011 & 0.310 & 0.010 & 0.002 & 0.300 & 0.001 \\
\hline br & 0.690 & 0.146 & 5.000 & 0.290 & 0.025 & 5.020 & 0.002 & $\mathrm{Yb}$ & 0.080 & 0.082 & 1.620 & 0.080 & 0.014 & 1.600 & 0.003 \\
\hline $\mathrm{Nd}$ & 3.070 & 0.732 & 21.910 & 1.110 & 0.155 & 19.850 & 0.017 & $\mathrm{Lu}$ & 0.010 & 0.016 & 0.190 & 0.010 & 0.003 & 0.180 & 0.001 \\
\hline $\mathrm{m}$ & 0.460 & 0.156 & 4.470 & 0.270 & 0.128 & 3.975 & 0.004 & $\sum$ REE & 15.48 & 3.42 & 117.50 & 6.44 & 0.71 & 110.53 & 0.09 \\
\hline $\mathrm{Eu}$ & 0.110 & 0.034 & 0.860 & 0.630 & 0.021 & 0.795 & 0.006 & LREE & 13.68 & 2.74 & 100.45 & 5.69 & 0.50 & 94.62 & 0.06 \\
\hline $\mathrm{Gd}$ & 0.440 & 0.112 & 3.520 & 0.290 & 0.018 & 3.350 & 0.004 & MREE & 1.55 & 0.49 & 13.04 & 1.55 & 0.21 & 12.08 & 0.02 \\
\hline$\Gamma \mathrm{b}$ & 0.070 & 0.024 & 0.560 & 0.050 & 0.005 & 0.550 & 0.001 & HREE & 0.25 & 0.20 & 4.01 & 0.20 & 0.02 & 3.83 & 0.01 \\
\hline Dy & 0.410 & 0.122 & 3.010 & 0.260 & 0.020 & 2.830 & 0.004 & $\mathrm{La}_{\mathrm{n}} / \mathrm{Yb}$ & 5.45 & 0.25 & 1.41 & 1.39 & 0.74 & 1.15 & 1.02 \\
\hline Но & 0.060 & 0.039 & 0.620 & 0.050 & 0.014 & 0.580 & 0.001 & $\mathrm{Ce}_{\mathrm{an}}$ & 0.22 & 0.88 & 1.01 & 0.93 & 0.067 & 1.01 & 0.58 \\
\hline
\end{tabular}

$\Sigma$ REE concentration in the dissolved fraction generally decreases and in the bottom sediments increases with increased salinity and $\mathrm{pH}$ in soda lakes. Primarily LREE (La-Nd) accumulate in the bottom sediments, the ratio of normalized values $\mathrm{La}_{\mathrm{n}} / \mathrm{Yb}_{\mathrm{n}}$ go up from 0.94 to 1.65 with an increase in salinity from 2.2 to $42.9 \mathrm{~g} / \mathrm{L}$. When the salinity of the water is more than $30 \mathrm{~g} / \mathrm{L}$, REE in absolute concentrations have mainly MREE (Sm-Ho) and HREE (Er-Lu), and $\Sigma$ REE content is tens of $\mu \mathrm{g} / \mathrm{L}$. As a rule the processes of bacterial sulfate-reduction are significantly manifested in these lakes; $\mathrm{HS}^{-}$water content is up to 10.3 $\mathrm{mg} / \mathrm{L}, \mathrm{DOC}$ concentration is several hundred $\mathrm{mg} / \mathrm{L}$ and Eh values decrease to $-146 \mathrm{mV}$. $\mathrm{La}_{\mathrm{n}} / \mathrm{Yb}_{\mathrm{n}}$ ratio in dissolved form decreases to 0.02 and increases to 1.64 and 17.4 in the suspension and in the sediments, respectively. In the profiles of distribution of the normalized values (not given in this article) REE differentiation is more pronounced than in lakes with oxidizing conditions.

Despite the presence in water of hydrosulfide $\mathrm{HS}^{-}$, lanthanides do not form their own sulphides $\mathrm{Ln}_{2} \mathrm{~S}_{3}$. Saturation of solutions is impossible, when solubility product (SP) for sulfide La $\left(10^{-26.3}\right.$ by [9]) keeps minimum and its activities product (AP) (on the average is $10^{-34}$ ) keeps maximum. Therefore, the absence of a pronounced positive Ce anomaly in the waters with reducing conditions (with $3^{+}$oxidation state) can be explained by the formation 
of poorly soluble hydroxide $\mathrm{Ce}(\mathrm{OH})_{3}\left(\mathrm{SP}=6.43 \times 10^{-26.4}\right.$ by [10]). In the oxidizing conditions stability of cerium in the waters can be controlled by hydroxide $\mathrm{Ce}(\mathrm{OH})_{4}$; its formation is possible for all lakes (AP is $10^{-41}$ and SP is $1.6 \times 10^{-55}$ the same link).

The accumulation of LREE in sediments may be explained by the formation of their own carbonates, in particular, parisite $\mathrm{CaCe}_{0.95} \mathrm{La}_{0.6} \mathrm{Nd}_{0.35} \mathrm{Pr}_{0.1}\left(\mathrm{CO}_{3}\right)_{3} \mathrm{~F}_{2}$ and bastnäsite $\mathrm{Ce}_{0.5} \mathrm{La}_{0.25} \mathrm{Nd}_{0.1} \mathrm{Pr}_{0.05} \mathrm{CO}_{3} \mathrm{~F}$; their solubility product is calculated by us with data ofGibbs energies given in [11], and they are $10^{-93.6}$ and $10^{-34.9}$, respectively. According to the average content in the soda lakes, activities product of parisite is $10^{-36}$ and of bastnäsite is $10^{-16}$, and for chloride lakes $-10^{-43}$ и $10^{-19}$, respectively. These numbers show that a relatively small value of solubility of these minerals can control the LREE content in the waters. The degree of saturation in both minerals is higher in soda lakes than in chloride lakes. The possibility of precipitation of lanthanides carbonates is confirmed by data on the newly precipitated carbonate crusts, which were selected in the coastal zone of one of soda lakes; $\Sigma$ REE content in these crusts is one order of magnitude more than in silt of the same lake. In this case, molar fractions of lanthanides (except $\mathrm{Ce}$ ) in the formed carbonate precipitate are close to parisite $(\mathrm{Ce}-0.75, \mathrm{La}-0.71, \mathrm{Nd}-0.40, \mathrm{Pr}-0.14)$ relative to their total content.

In chloride lakes accumulation of REE in the water and sediments is lower than in soda lakes. Correlations between dissolved REE and elements hydrolysates - Al, Fe and Mn are not significant $(\mathrm{r}<0.50)$, but the bonds between biogenic elements, especially with phosphorus and heavy lanthanide group are getting stronger. In the bottom sediments REE content is higher than in aqueous filtrates, but in comparison to soda lakes the REE accumulation both in the bottom sediments and aqueous filtrates is lower. Graphs of the normalized values (not given) on the majority of the lakes are slightly differentiated. $\mathrm{La}_{\mathrm{n}} / \mathrm{Yb}_{\mathrm{n}}$ ratio in dissolved form is 0.74 , in sediments and suspensions is 1.31 and 1.15, respectively.

According to calculation, lanthanides occur in the lake waters mainly in the form of carbonate ions $\left(\mathrm{LnCO}_{3}\right)^{+}$. The proportion of carbonate associate of lutetium significantly reduces in soda lakes, but the percentage of oxyhydroxide $(27.3 \%)$ and acetate $(7.8 \%)$ complexes increases, while its activity $\left(\mathrm{LnCO}_{3}\right)^{+}$in chloride lakes remains relatively high (above $80 \%$ ). Both soda and chloride waters are saturated by dolomite $\mathrm{CaMg}\left(\mathrm{CO}_{3}\right)_{2}$, chlorite $\mathrm{Mg}_{4.5} \mathrm{Al}_{3} \mathrm{Si}_{2.5} \mathrm{O}_{10}(\mathrm{OH})_{8}$, and iron hydroxide $\mathrm{Fe}(\mathrm{OH})_{3}$; chloride waters are saturated by magnesite $\mathrm{MgCO}_{3}$, and soda waters by calcite $\mathrm{CaCO}_{3}$ and under reducing conditions by hydrotroilite $\mathrm{FeS}_{2}\left(\mathrm{H}_{2} \mathrm{O}\right)$.

\section{Conclusions}

Accumulation of REE in soda lakes is more intensive in comparison to chloride lakes. When the water salinity increases, total content of REE in the dissolved form decreases at a certain growth of HREE and it increases in sediments. LREE in dissolved form do not accumulate, it can be explained not only by their sorption on oxyhydroxide compounds of iron and manganese (formed in oxygen waters), but also by the formation of their own fluorcarbonate minerals (parisite and bastnäsite). Saturation in these minerals can be observed in all lakes, and the degree of saturation in soda lakes is several orders of magnitude larger than in chloride lakes, that is why REE accumulate more in the bottom sediments of soda lakes. According to the calculations equilibrium is achieved also with cerium hydroxide; in a reducing medium it forms sparingly soluble compounds $\mathrm{Ce}(\mathrm{OH})_{3}$ and in oxidative conditions $-\mathrm{Ce}(\mathrm{OH})_{4}$.

It is explained by the different genesis of the lakes. The chemical composition of soda lakes is formed mainly due to the process of water-rock interaction and sulphate-reduction 
and to a lesser extent due to evaporation. This is confirmed by the presence of the highest $\mathrm{pH}$ values (9.0-10.7). The hydrolysis of aluminosilicates and sulfate-reduction provide an increase in $\mathrm{pH}$ and an increased content of $\mathrm{HCO}_{3}{ }^{-}$and $\mathrm{CO}_{3}{ }^{2-}$. High $\mathrm{pH}$ values and $\mathrm{HCO}_{3}{ }^{-}$ and $\mathrm{CO}_{3}{ }^{2-}$ contents, in turn, lead to maximum loss of calcite, gaylussite, bastnäsite, parisite, etc. All these processes contribute to the separation of REE and the accumulation of HREE. The degree of interaction between the chloride lake waters and aluminosilicates is relatively small, hence the low contents of $\mathrm{HCO}_{3}{ }^{-}$and $\mathrm{CO}_{3}{ }^{2-}$ and $\mathrm{REE}$, as well as a slight differentiation of REE.

This work was prepared under the project IX.137.1.2 "Geochemistry of rare and rare-earth elements in natural and geotechnogenic landscapes and hydrogeochemical systems".

\section{References}

1. A.V. Dubinin, Lithology and Mineral Resources 39, 289-307 (2004)

2. Svetlana V. Borzenko, Leonid V. Zamana, Daria S. Suvorova, Acta Geologica Sinica. 88 (supp. 1), 123-124 (2014)

3. L.V. Zamana, Doklady Earth Sci. 428, 1188-1191 (2009)

4. S.V. Borzenko, L.V. Zamana, Geochemistry Int. 49, 253-261 (2011)

5. A.P. Vinogradov, Geokhimia 7, 555-571 (1962) (in Russian)

6. L.P. Gromet, R.F. Dymek, L.A. Haskin, R.L. Korotev, Geochim. Cosmochim. Acta 48, 2469-2482 (1984)

7. M.B. Bukaty, Bulletin Tomsk Polytechnic University 305, 348-365 (2002) (in Russia).

8. S.L. Shvartsev, M.N. Kolpakova, V.P. Isupov, A.G. Vladimirov, S. Ariunbileg, Geochemistry Int. 52, 388-403 (2014)

9. A.A. Marakushev, N.M. Gavrilov, S.A. Marakushev, Doklady Earth Sci. 397, 840845 (2004)

10. D.E. Chirkst, O.L, Lobacheva, I.V. Berlinskii.,Russian J of Physical Chem. 84, 20472050 (2010)

11. A.P. Gysi, A.E. Williams-Jones, Chem Geol. 21, 87-101 (2015) 